Article

\title{
Identifying Key Knowledge Gaps to Better Protect Biodiversity and Simultaneously Secure Livelihoods in a Priority Conservation Area
}

\author{
Anke S. K. Frank *(i) and Livia Schäffler \\ Zoological Research Museum Alexander Koenig - Leibniz Institute for Animal Biodiversity, Adenauerallee 160, \\ 53113 Bonn, Germany; 1.schaeffler@leibniz-zfmk.de \\ * Correspondence: a.frank@leibniz-zfmk.de; Tel.: +49-228-9122-247
}

Received: 23 September 2019; Accepted: 11 October 2019; Published: 15 October 2019

\begin{abstract}
Global agreements like the Sustainable Development Goals (SDGs) and Achi Biodiversity Targets (ABTs) aim to secure human well-being and to protect biodiversity, but little progress has been made in reaching these aims. The key role of biodiversity in securing human well-being is rarely considered a priority - instead short-term economic profits benefiting a few are prioritized. Particularly where local livelihoods rely on resources of protected areas for immediate survival, top-down enforced biodiversity conservation often increases social inequality, hunger and poverty and thus regularly fails. Identifying key knowledge gaps helps to adjust political priority setting and investment strategies to assess conservation threats and improve natural resource management. Since acting usually occurs at a local or regional scale, we focused on a priority conservation area in one of the world's poorest countries - the dry deciduous forests of western Madagascar. We aimed to identify key knowledge gaps in this area which need to be filled to better protect biodiversity and simultaneously ensure well-being of the local poor. We consulted 51 predominantly Malagasy experts using questionnaires. These questionnaires listed 71 knowledge gaps we collated from the literature which the experts were asked to rank by importance. Experts were encouraged to list additional knowledge gaps. Averaging the scores of all experts, we identified the top 10 knowledge gaps. Two political knowledge gaps addressing the need to determine strategies which improve law enforcement and reduce corruption ranked highest, followed by an ecological one concerning appropriate restoration and a socio-economic one regarding economic benefits locals gain from biodiversity. The general knowledge gap perceived as most important addressed strategies for long-term funding. Only one additional knowledge gap was identified: the impact of climate change-driven human migration from southwestern to central western Madagascar on socio-economic problems and its impacts on natural resources We linked the identified top 10 knowledge gaps as well as the additional knowledge gap suggested by experts to the SDGs, ABTs and $2{ }^{\circ} \mathrm{C}$ target of the Paris Climate Agreement, and discussed why these gaps were considered a priority. This research highlights important ecological, socio-economic and political research priorities and provides guidelines for policy makers and funding organizations.
\end{abstract}

Keywords: Aichi Biodiversity Targets; biodiversity conservation; dry deciduous forest; human well-being; Madagascar; Paris Climate Agreement; Sustainable Development Goals

\section{Introduction}

\subsection{Theoretical Background}

The Sustainable Development Goals (SDGs), the Aichi Biodiversity Targets (ABTs) and the $2{ }^{\circ} \mathrm{C}$ target of the Paris Climate Agreement all aim to secure human well-being in a sustainable world [1-3]. Even though human wellbeing essentially relies on the preservation of biodiversity to ensure ecosystem 
functioning $[4,5]$, current global conservation efforts fail to halt biodiversity decline, which occurs at an unprecedented rate and will continue to do so due to ongoing as well as new threats [6-8]. This has extensive negative effects on economy and society due to ecosystem service losses [9] and clearly demonstrates that the key role of biodiversity for human well-being is not easily recognized by politicians aiming to achieve these global targets. Despite recent efforts to uncover the synergies and trade-offs between the goals and targets of these conventions [10-13], there remains a high risk that nations will cherry-pick a few goals suiting their priorities and fail to tackle those harder to accomplish [14]. Similarly, the ABTs have been criticized for their conflicting interests and lack of indicators, particularly concerning the drivers of biodiversity loss $[15,16]$. While new indicators are constantly being developed and others improved or upgraded regarding their availability for more countries [17], essential knowledge gaps remain, particularly concerning data from developing countries [18]. Identifying key knowledge gaps is important for assessing biodiversity threats [19] as well as for improving monitoring, management and investment strategies [20,21]. Approaching the end of the United Nations Decade on Biodiversity [22], we aim to identify key knowledge gaps concerning biodiversity loss in a particular priority conservation area as an example for many other priority conservation areas to be used by practitioners to streamline funds, resources and efforts to tackle the ongoing biodiversity crisis while simultaneously secure livelihoods.

Most people's well-being predominantly depends on ecosystem services provided by terrestrial biodiversity. However, there are trade-offs between protection of life on land and human wellbeing. Strict area protection for conservation has frequently cut off the local poor from essential resources and thus led to famine and increased social inequality threatening their survival [23-25]. We therefore have focused our knowledge gap search on the protection of "Life on land" (SDG 15) and major trade-offs of this central goal with SDG 2 (zero hunger-directly connected to food security through agricultural land use), and SDG 10 (reduced inequalities) (Figure 1). The predominant trade-off between SDG 2 and SDG 15 is the expansion of agricultural areas to reduce hunger (SDG 2) resulting in competition for land with SDG 15 aiming to protect natural ecosystems like forests and their biodiversity [15]. Progress in achieving SDG 15 has often reduced that of SDG 10 [26-28]. Social and material inequality have been shown to be harmful to the environment and thus to people's health and well-being $[29,30]$.

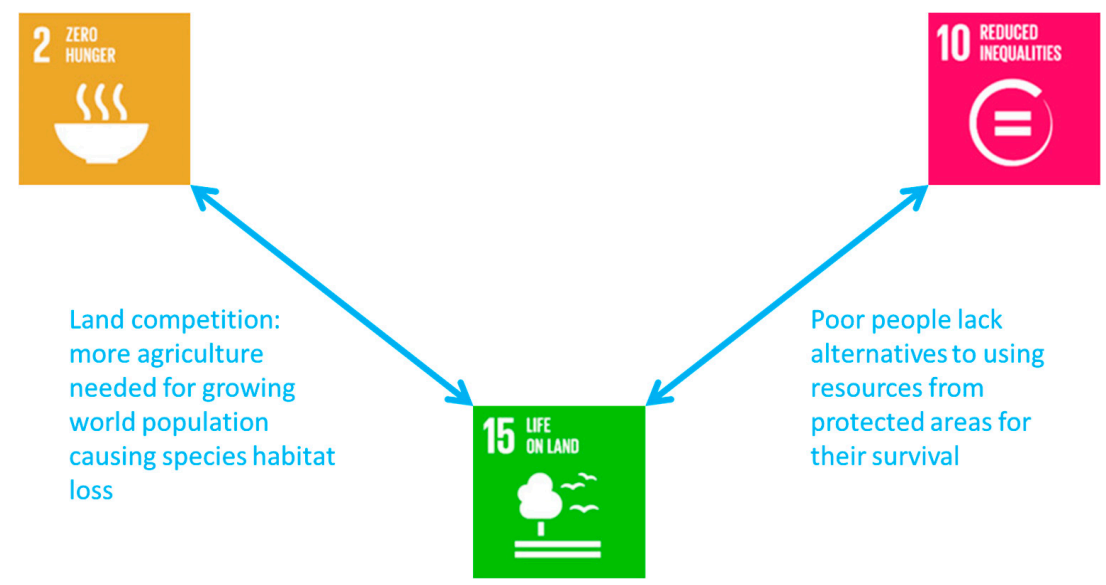

Figure 1. Trade-offs between Sustainable Development Goal (SDG) 2, SDG 10 and SDG 15.

\subsection{Regional Focus Area: the Dry Deciduous Forests of Western Madagascar}

As countries and regions differ in their demographics, geographies and governance [31], and are differently affected by climate change and biodiversity threats [32], we selected one regional example which promises high conservation payoff (in terms of biodiversity protection): the dry deciduous forest in western Madagascar. Madagascar is one of many developing countries rich in biodiversity and natural resources, but economically highly disadvantaged [33]. It is one of the poorest countries on Earth, where malnutrition is prevalent and where about $80 \%$ of the population lives below the poverty line [33,34]. Despite a growth in GDP, poverty has been increasing [35] and over half of 
the population faces food insecurity [36]. Madagascar's population has increased by $400 \%$ over the last five decades to about 23.5 million [37,38]. This massive population growth, demanding an increasing share of land for agriculture, can be considered the major indirect driver of dry forest loss in western Madagascar [39]. However, political turmoil, insecurity and corruption are also major issues in Madagascar. Environmental crimes encompass illegal land clearance for large-scale agricultural expansion, illegal timber and wildlife trade, and mining [40]. Political crises occur on an almost decadal basis, preventing transparency and accountability of governmental actions [33,41,42]. Currently, Madagascar is listed at fifth position in the global ranking of increased risk of notable changes to the Global Peace Index [43], dropped severely in the Rule of Law Index [40], and only ranks 155th out of 180 nations in the International Corruption Perception Index [44]. Moreover, Madagascar ranks in the bottom 10 of 51 African countries assessed for their performance in reaching the SDGs [45]. Due to successful international awareness-raising of the uniqueness of and threats to Madagascar's biodiversity, the country has seen a quadrupling in protected areas since 2003, with about $10 \%$ of the country being protected for conservation $[46,47]$. However, like in many tropical countries, conservation has focused on rainforests in the east of Madagascar, while the diverse dry forests in the west and south have rather been neglected [39,48,49]. But even where protected areas had been declared, these largely failed to prevent forest loss and degradation $[33,50,51]$ due to a lack of law enforcement and high levels of corruption [33,40,42,47]. At least 13 protected areas are considered mere "paper parks" as they are totally devoid of management [47]. Generally, many knowledge gaps remain in Madagascar for achieving fair and equitable biodiversity conservation [52]. We chose the highly threatened dry deciduous forest of western Madagascar because forest losses predominantly caused by slash-and-burn agriculture and illegal logging are still dramatic there despite some national and international conservation attempts. Almost three quarters of the population live from subsistence farming practicing slash-and-burn agriculture $[46,53]$ due to lack of alternatives but also because this farming practice is part of the people's cultural identity [54,55]. Slash-and-burn agriculture is conducted in two stages: during the dry season (June to September), woody undergrowth is cut and stacked around trees; at the beginning of the growth season (October) these piles of undergrowth are ignited, resulting in the destruction of all vegetation except for a few dead blackened tree trunks [56]. This form of agriculture requires little labor and-because of the ashes-requires no addition of nutrients for two to five years [57]. Afterwards, the land needs to be left fallow for several years (at least 20 years within the dry forest-see [58]). A reduced or lacking fallow period results in severe nutrient loss and too frequent burning favors the establishment of introduced and invasive species, preventing native species regeneration $[58,59]$. A growing need for agricultural land of the rapidly increasing population hinders sustainable management that would allow for sufficient regeneration time of soils in agricultural fields. Thus, the rate of turning primary forests into agricultural fields by slash-and-burn practices to generate fertile farmland is increasing. About $40 \%$ of the forest have been lost since 1970 [39]. Fragmentation has been immense, so that few areas of primary forest larger than 800 ha remain - too small to contain viable populations of many species like larger lemurs [60]. Fragmentation also hinders animals to disperse and migrate to cope with climate change conditions [61,62]. The largest remaining area of dry deciduous forest occurs in central-western Madagascar [63]: Menabe Central ranks among the hottest biodiversity hotspots in the world [60], particularly due to its exceptionally high rate of endemism and intense anthropogenic threats [64]. While the total number of species is lower in the dry than in the humid forests, species richness is exceptionally high by global comparison with other dry forests [39]. Madagascar's dry forests harbor several locally endemic vertebrate species such as Madame Berthe's mouse lemur (Microcebus berthae), the giant jumping rat (Hypogeomys antimena), the narrow-striped mongoose (Mungotictis decemlineata), and plenty of other endangered species [65-68]. $M$. berthae, the smallest primate in the world, is particularly vulnerable to anthropogenic disturbances and restricted to core habitats of this biome $[66,69,70]$. Without immediate protection of its habitat, this species will likely be extinct by 2050 [63], just as many other vertebrate species of lemurs, rodents or tenrecs have already been driven to extinction [39]. This is of concern due to the roles these 
species play for ecosystem functioning, its regeneration abilities and hence long-term persistence which for example depends on the seed dispersing role of lemurs [71]. Western Madagascar's dry deciduous forests are also considered of high conservation importance by a range of other approaches identifying priority conservation areas, for example the "Global 200" ecoregions [72] due to many endemic and endangered species and the Key Biodiversity Areas with a high biological value and intense anthropogenic pressure [73,74].

With respect to the people inhabiting this priority conservation area, social inequality is a huge issue hampering sustainable resource utilization as well as human well-being. Despite ambitious intentions, limited understanding of social-economic and ecological contexts prevented the realization of an effective protected area network [47]. For example, in spite of plans to involve communities in decision-making processes under the Durban Vision aiming to triple the amount of protected areas [47], conservation decisions have mostly been top-down enforced, sharply restricting or banning the use of local resources on which the local population relied [48,75]. This led to increased hunger, poverty and inequality of the already poor population as well as widespread criticism of the prioritization of the survival of lemurs over the survival of people [ibid.]. Due to funding, personnel and time restrictions of this project, we were unable to involve local community members in the collation and ranking of knowledge gaps in this study and therefore had to rely on predominantly academic experts for our knowledge gap ranking. To increase the chance of locals' needs to be considered in the ranking of knowledge gaps, we asked our participants whether they had work experience with local people.

A range of attempts have been made to identify knowledge gaps or important research questions, e.g., in the reports of the Intergovernmental Platform for Biodiversity and Ecosystem Services (IPBES) or by the yearly scan for the most important 100 ecological research questions at the time (see [21] at the global scale, and [76] at the national (UK) scale). However, acting usually occurs at the regional or local level and thus considering the specific local or regional conditions and needs of people at this level is important [77]. By choosing a regional example (i.e., the western dry deciduous forest of Madagascar) and conducting a consultation exercise using questionnaires with professionals from various fields (including subsistence farming and forest biodiversity, human development, governance, etc.), we followed an inclusive approach to "overcome the limitations of a consultation exercise of global aspirations" (Oldekop et al. 2016).

\subsection{Aims of Our Study}

We aimed to provide practitioners, politicians and funding bodies with a top 10 list of knowledge gaps concerning the slash-and-burn problematic in western Madagascar which need to be filled most urgently. This top 10 list is intended to be used as a guideline for decision making in research efforts and funding distribution. We undertook the following steps to pinpoint these key knowledge gaps:

(1) Identify knowledge gaps concerning biodiversity conservation with a focus on SDGs 2, 10 and 15 at the global scale to spot knowledge gaps relevant to the slash-and-burn problematic in western Madagascar.

(2) List knowledge gaps relevant for the slash-and-burn problematic threatening the dry deciduous forest in western Madagascar and sort into categories (ecological, socio-economic, political and general knowledge gaps).

(3) Identify the top 10 knowledge gaps which need to be tackled most urgently to enhance biodiversity conservation success while securing local livelihoods in our focal region (dry deciduous forests of western Madagascar) by using the help of experts via questionnaires.

(4) Identify links of these key knowledge gaps to our focal and any other goal and target of the SDGs and ABTs as well as the $2{ }^{\circ} \mathrm{C}$ target of the Paris Climate Agreement as these goals and targets are highly interrelated $[10,12,78]$.

(5) Discuss previous attempts to fill some of these knowledge gaps in Madagascar (e.g., by checking Madagascar's National Biodiversity Strategy and Action Plan (NBSAP). 
In this paper, we will present and discuss the expert-identified top 10 priority knowledge gaps, link them to the SDGs, ABTs and $2{ }^{\circ} \mathrm{C}$ target of the Paris Climate Agreement and examine the effects of experts' backgrounds on the ranking to check whether a particular type of characteristic (e.g., profession, age, gender) influenced the ranking scores.

\section{Materials and Methods}

\subsection{Knowledge Gap Identification at the Global Scale and Sorting into Categories}

In a first literature-based step, knowledge gaps related to the trade-offs between SDG 15 (life on land) and SDG 2 (zero hunger) as well as SDG 10 (reduced inequality) were identified at a global scale to spot knowledge gaps that are not directly addressed in the regional literature dealing with the slash-and-burn problematic in western Madagascar. We conducted a modified "snowball principle" based literature search using any paper which yielded relevant knowledge gaps to identify further relevant papers, as well as to check for subsequent citing publications $[79,80]$. Papers studied for knowledge gaps were restricted to those from the last 10 years, as recommended for a snowball literature search [81]. Further knowledge gaps were added by the authors based on their own professional experience.

Knowledge gaps relevant for the slash-and-burn problematic in dry deciduous forests of western Madagascar were listed $(n=71)$. Most of the literature sourced to select relevant knowledge gaps for this area concerned the core area of Menabe Central. Again, we used the snowball principle for our literature search as well as judgement of relevance by author LS who has extensive work experience in central western Madagascar. We separated these 71 knowledge gaps into ecological $(n=26)$, socio-economic $(n=24)$, and political categories $(n=14)$, because these categories relate to the different spheres of sustainability (i.e., economic, social, environmental and political, see [82] and because it is necessary to identify solutions that have "traction in the social, economic, and political arenas in which conservation action must take place" [83]). In addition, we listed the category "general" $(\mathrm{n}=7)$ —comprising knowledge gaps that apply to any of the other categories (see Questionnaire in the Supplementary Material S1).

\subsection{Identification of Key Knowledge Gaps through Expert Ranking}

Knowledge gaps relevant for the slash-and-burn problematic in western Madagascar were listed in a questionnaire (see S1) designed following the guidelines of McLafferty [84]. To keep the questionnaire short, we combined some knowledge gaps which were closely linked. After discussion of the questionnaires with some experts of our focal area in Madagascar, the questionnaires were refined and then sent to representatives from universities and other research institutions as well as NGOs that have a long professional experience in Madagascar (via Email or LinkedIn). For time and logistic reasons, we could not include local people in the consultation process. However, to make sure that their perspective was represented, we have consulted experts that had been predominately working with rural people. We used snowball sampling [85] to recruit further experts by asking those contacted to spread the questionnaires further via their own personal networks.

The questionnaires consisted of two parts. Part I asked experts about their background (position/ occupation, institution/ organization, nationality, age) and Madagascar work experience, i.e., what type of work related to the slash-and-burn problematic they have done, for how long they have worked in this field, whether they have worked with locals and if so, in which context. We checked these background variables to check whether they qualified as experts and to determine potential bias in ranking scores. For example, people which feel strongly attached to a place, younger people, as well as women are often more environmentally concerned than those with little place attachment, older people, and men, respectively [86]. Age and work experience were divided into categories (age: $<25$ years, between $25-35$ years, 36-45 years, $46-65$ years and $>65$ years; work experience: $<1$ year, 1-5 years, $6-10$ years, $>10$ years). Additionally, participants could provide any other background information about themselves they considered relevant to define their expertise. In part II, experts 
were introduced to the ranking scheme and then asked to rank the knowledge gaps by importance to pinpoint key knowledge gaps. The ranking categories reached from 0 (no priority) to 3 (extremely high priority). To accommodate for the lack of expert engagement in compiling the list of knowledge gaps, experts were given the opportunity to suggest additional knowledge gaps which they considered more important than those they ranked as a knowledge gap of category 3. A copy of the full questionnaire, including the cover letter and a last page with options for comments, optional email provisioning to receive information about the project outcome, thanks, and the declaration of consent can be found in the Questionnaire provided in S1.

Questionnaires were created in Adobe Acrobat professional. The ranking categories were fixed to the ranking scheme (0-3), text sections allowed unlimited words and no grammar correction was chosen to avoid false auto-correction. The survey was conducted in February and March 2019. To keep the identity of our experts anonymous, responses of individuals are not presented in a personalized way but only in non-assignable categories (Table S2a,b).

Results of this survey are of mainly descriptive nature. We ranked knowledge gaps by their mean (highest to lowest). Most background variables were unsuitable to use for statistical tests as we did not have enough scores for each category (position/occupation, institution/organization, nationality, age, years of work experience in western Madagascar) or because almost all participants belonged to just one category, i.e., $82 \%$ had $>10$ years of work experience and $96 \%$ had work experience with locals. The variables "position/occupation" and "institution/organization" had too many levels to be tested. Other variables with several levels were merged together in the following way: The five age groups were merged into young (>25 and 25-35), medium age (36-45) and old (46-65, >65) age. The variable 'nationality' was reduced to two levels: Malagasy and other nationalities. Background variables with sufficiently even distribution were tested for their influence in ranking the knowledge gaps using Kruskal-Wallis tests with Holm's adjusted p-values controlling for family-wise Type I errors $[87,88]$. All analyses were performed in R 3.6.1 [89]. Due to well-known interlinkages of our focal SDGs $(2,10$ and 15) to other SDGs, various ABTs and the $2{ }^{\circ} \mathrm{C}$ target, e.g., [10,12], we linked our top 10 knowledge gaps to other relevant targets of these agreements, thus pointing out which targets of these agreements will be better reached when filling these priority knowledge gaps.

\section{Results}

\subsection{Background Information of Participants}

A total of 51 participants returned the questionnaires (Table S2a), $67 \%$ of them were male. Most respondents were between 25-35 years old (37\%), followed by those between 36-45 (29\%) and $46-65$ years $(26 \%)$ which corresponded well to the young Malagasy society. Younger than 25 and older than 65 years were, in both age groups, only $4 \%$ of all participants. $77 \%$ of all participants were of Malagasy origin. The spectrum of positions covered various backgrounds. Most were researchers $(25 \%)$, followed by students and managers (14\% each), technical staff and coordinators $(8 \%)$, lecturers ( $6 \%$ each), and others $(<5 \%$ each). Accordingly, participants were associated with a range of organizations. Most were from universities $(29 \%)$, followed by NGOs $(26 \%)$, research centers $(10 \%)$, and the UN (6\%). All others contributed less than $5 \%$ each (e.g., governments, associations, etc.; see Table S2b for details). $82 \%$ had more than 10 years of work experience in western Madagascar while no participant had $<1$-year experience. Over $96 \%$ had work experience with locals.

\subsection{Top 10 Knowledge Gaps across Categories}

In two cases, knowledge gaps had equal mean scores, so that twelve knowledge gaps made it into the top 10 (Table 1). These consisted of four political, three ecological, three socio-economic and two general knowledge gaps (Table 1, Figure 2). With a mean of 2.68, more knowledge about "Strategies on how to improve justice/fairness/enforcement of laws/rules" was considered most important by a majority of participants. The knowledge gap with the second highest mean (2.67) was "Role of corruption in illegal activities (also beyond logging) and ways to reduce corruption". In the third 
position ranked the ecological knowledge gap "Appropriate forest restoration methods in conjunction with biodiversity protection and sustainable use" (mean 2.65). The fourth highest ranking knowledge gap was a socio-economic one: "Economic benefits for local small-holder farmers from biodiversity, e.g., potential of ecotourism, payment for ecosystem services (PES), and other off-set schemes on their well-being" (mean 2.61). The political knowledge gaps "Strategies on how to improve security from violence/theft/corruption" (mean 2.59) and "Strategies to improve long-term funding" (mean 2.50) ranked fifth and sixth. Rank seven was shared by an ecological ("Appropriate livestock management practices and fire regimes") and a socio-economic ("Effectiveness of education and awareness-raising on biodiversity conservation") knowledge gap (mean 2.45). The eight highest ranking knowledge gap was an ecological one: "Ecosystem services (ES) at risk from slash-and-burn as well as associated extractive activities" (mean 2.44). Two knowledge gaps shared rank nine (mean 2.43), a socio-economic ("Traditional knowledge about sustainable natural resource use") and a general one ("Frequent and regular scenario updates based on long-term monitoring"). The lowest ranking knowledge gap of the Top 10 list was a general one: "Interdisciplinary work to generate most comprehensive data sets" (mean 2.41). In Table S3 we provide the ranking of all 71 knowledge gaps.

Table 1. Linkages between the top 10 knowledge gaps ordered by mean ranking score and relevant Sustainable Development Goal (SDGs) ${ }^{1}$, Achi Biodiversity Targets (ABTs) $)^{2}$ and the $2{ }^{\circ} \mathrm{C} \operatorname{target}^{3}$ of the Paris Climate Agreement. Note that due to the same mean values of some knowledge gaps, a rank of the top 10 rankings can harbor more than one knowledge gap.

\begin{tabular}{|c|c|c|c|c|c|c|c|}
\hline Top & Category & Knowledge Gap & Mean & SD & SDG & ABT & $\begin{array}{l}2{ }^{\circ} \mathrm{C} \\
\text { Target }\end{array}$ \\
\hline 1 & Political & $\begin{array}{l}\text { Strategies on how to improve } \\
\text { justice/fairness/enforcement of laws/rules }\end{array}$ & 2.68 & 0.583 & $10,12,16$ & 4 & \\
\hline 2 & Political & $\begin{array}{l}\text { Role of corruption in illegal activities (also } \\
\text { beyond logging) and ways to reduce corruption }\end{array}$ & 2.67 & 0.589 & $10,12,16$ & 4 & \\
\hline 3 & Ecological & $\begin{array}{l}\text { Appropriate forest restoration methods in } \\
\text { conjunction with biodiversity protection and } \\
\text { sustainable use }\end{array}$ & 2.65 & 0.627 & $12,13,15$ & $4,7,14,15$ & yes \\
\hline 4 & Socio-economic & $\begin{array}{l}\text { Economic benefits for the local small-holder } \\
\text { farmers from biodiversity: e.g., potential of } \\
\text { ecotourism, PES and other offset schemes on } \\
\text { their well-being }\end{array}$ & 2.61 & 0.695 & $8,10,15$ & 11,14 & \\
\hline 5 & Political & $\begin{array}{l}\text { Strategies on how to improve security from } \\
\text { violence/theft/corruption }\end{array}$ & 2.59 & 0.726 & 10,16 & & \\
\hline 6 & Political & Strategies to improve long-term funding & 2.51 & 0.731 & & 20 & \multirow{3}{*}{$\begin{array}{l}\text { yes } \\
\text { yes }\end{array}$} \\
\hline \multirow[t]{2}{*}{7} & Ecological & $\begin{array}{l}\text { Appropriate livestock management practices } \\
\text { and fire regimes }\end{array}$ & 2.45 & 0.832 & 13,15 & 7 & \\
\hline & Socio-economic & $\begin{array}{l}\text { Effectiveness of education and awareness } \\
\text { raising on biodiversity conservation }\end{array}$ & 2.45 & 0.832 & 4 & 1 & \\
\hline 8 & Ecological & $\begin{array}{l}\text { Ecosystem services (ES) at risk from } \\
\text { slash-and-burn as well as associated extractive } \\
\text { activities }\end{array}$ & 2.44 & 0.760 & 13,15 & 7 & yes \\
\hline \multirow[t]{2}{*}{9} & General & $\begin{array}{l}\text { Frequent and regular scenario updates based on } \\
\text { long-term monitoring }\end{array}$ & 2.43 & 0.755 & & 7,20 & \\
\hline & Socio-economic & $\begin{array}{l}\text { Traditional knowledge about sustainable } \\
\text { natural resource use }\end{array}$ & 2.43 & 0.728 & & $7,18,19$ & \\
\hline 10 & General & $\begin{array}{l}\text { Interdisciplinary work to generate more } \\
\text { comprehensive data sets }\end{array}$ & 2.41 & 0.669 & 17 & $18,19,20$ & \\
\hline
\end{tabular}

${ }^{1}$ SDG 1: No poverty, SDG 2: Zero hunger, SDG 3 Good health and well-being, SDG 4: Quality education, SDG 5 Gender equality, SDG 6 Clean water and sanitation, SDG 7: Affordable and clean energy, SDG 8: Decent work and economic growth, SDG 9: Industry, innovation and infrastructure, SDG 10: Reduced inequalities, SDG 11: Sustainable cities and communities, SDG 12: Responsible consumption and production, SDG 13: Climate action, SDG 14: Life below water, SDG 15: Life on land, SDG 16: Peace and justice, strong institutions, SDG 17: Partnerships for the goals. 2 ABT 1: Awareness of biodiversity increased, ABT 2: Biodiversity values integrated, ABT 3: Incentives reformed, ABT 4: Sustainable production and consumption, ABT 5: Habitat loss halved or reduced, ABT 6: Sustainable management of aquatic living resources, ABT 7: Sustainable agriculture, aquaculture and forestry, ABT 8: Pollution reduced, ABT 9: Invasive alien species prevented and controlled, ABT 10: Ecosystem vulnerable to climate change, ABT 11: Protected Areas, ABT 12: Reducing the risk of extinction, ABT 13: Safeguarding genetic diversity, ABT 14: Ecosystem services, ABT 15: Ecosystem restoration and resilience, ABT 16: Access to and sharing benefits from genetic resources, ABT 17: Biodiversity strategies and action plans, ABT 18: Traditional knowledge, ABT 19: Sharing information and knowledge, ABT 20: Mobilizing resources from all sources. 3 Until 2100 keep warming well below $2{ }^{\circ} \mathrm{C}$. 


\subsection{Links of the Top 10 Knowledge Gaps to the SDGs, ABTs and $2{ }^{\circ} \mathrm{C}$-Target of the Paris Climate Agreement}

While we focused on SDG 2, 10 and 15 when identifying our knowledge gaps at the global scale, we are aware of the interlinkages of these SDGs with other SDGs, various ABTs and the $2{ }^{\circ} \mathrm{C}$ target $[10,12]$. Therefore, we linked the knowledge gaps identified for our focus area to other relevant SDGs, ABTs and the $2{ }^{\circ} \mathrm{C}$ target (Table 1, Figure 2). Ecological knowledge gaps identified within the top 10 knowledge gaps were related SDG 12 (Responsible consumption and production), SDG 13 (Climate change) and to SDG 15 (Life on Land), ABT 7 (Sustainable agriculture, aquaculture and forestry) and the $2{ }^{\circ} \mathrm{C}$ target (Table 1, Figure 2). Political knowledge gaps were most closely related to SDG 10 (Reduced inequalities), SDG 12 (Responsible consumption and production) and SDG 16 (Peace and justice, strong institutions), as well as ABT 4 (Sustainable production and consumption) and ABT 20 (Mobilizing resources from all sources) (Table 1, Figure 2). Socio-economic knowledge gaps were linked to SDG 4 (Quality education), SDG 8 (Decent work and economic growth), SDG 10 (Reduced inequalities) and SDG 15 (Life on land), as well as to ABT 1 (Awareness of biodiversity increased), ABT 11 (Protected areas), ABT 14 (Ecosystem services), ABT 18 (Traditional knowledge) and ABT 19 (Sharing information and knowledge) (Table 1, Figure 2). General knowledge gaps are linked to SDG 17 (Partnerships for the goals), ABT 7 (Sustainable agriculture, aquaculture and forestry), ABT 19 (Sharing information and knowledge) and ABT 20 (Mobilizing resources from all sources).

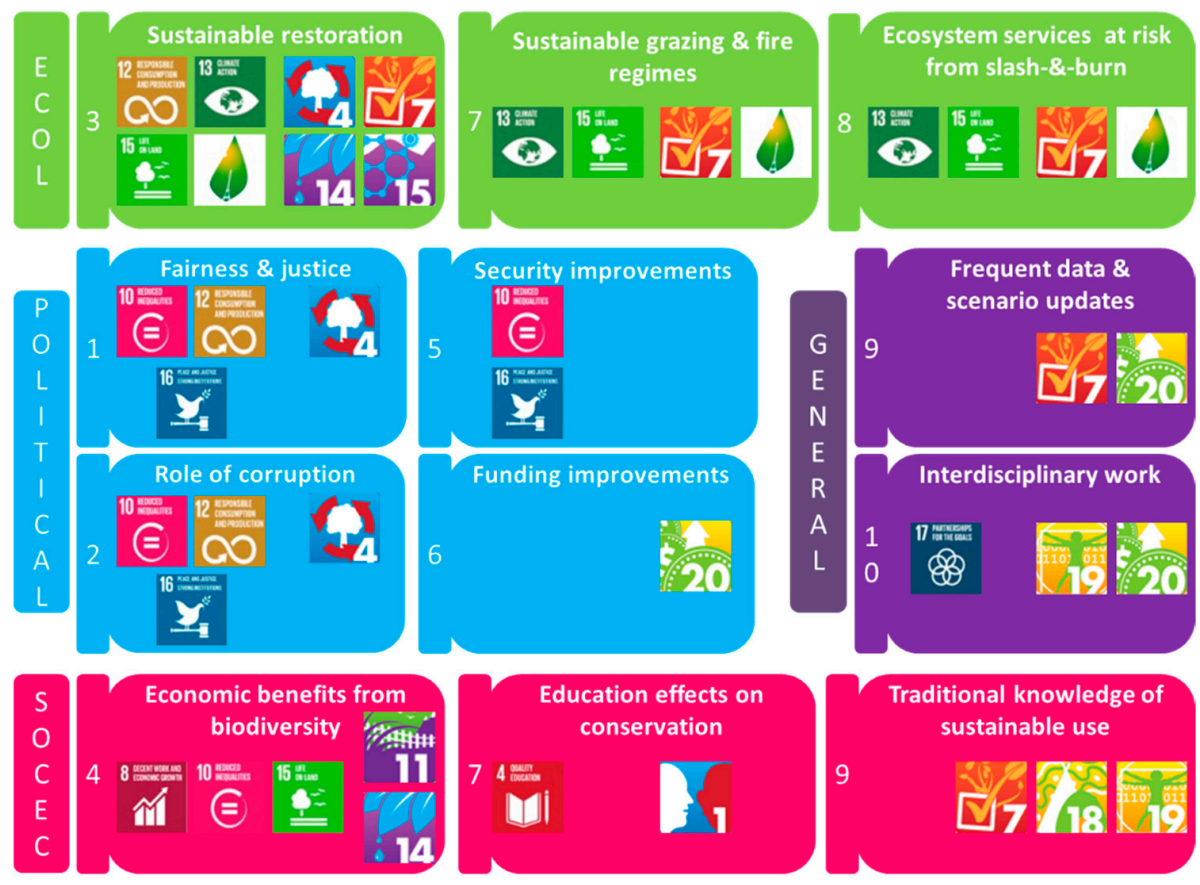

Figure 2. Overview of the expert-identified top 10 knowledge gaps (wording shortened for display) concerning the slash-and-burn problematic in the dry deciduous forests of Western Madagascar grouped by category (ECOL, POLITICAL, GENERAL, EOCEC) and linked to the SDGs (SDG symbols), Achi Biodiversity Targets (ABTs) (ABT symbols) and $2{ }^{\circ} \mathrm{C}$ target of the Paris Climate Agreement (COP 11 logo as symbol). ECOL: Ecological; SOCEC: Socio-economic. The full wording of the knowledge gaps can be seen in Table 1. The numbers of the thin tiles represent the ranking position within the top 10.

\subsection{Effects of Gender, Nationality and Age on Ranking Knowledge Gaps}

Most knowledge gaps were ranked similarly by male and female participants (Table S4a). This was true for all socio-economic and ecological, and all but one general ("Better data quality/reliability"), as well as two political knowledge gaps ("Strategies on how accountability of institutions/governments can be strengthened", "Effects of conservation activities and sustainable use of biodiversity on political 
achievements") which were ranked higher by women than men (Table S4a, Figure S1a). However, this affected none of the top 10 knowledge gaps (Table 1).

Rankings of knowledge gaps by Malagasy and other nationalities only differed for one general knowledge gap: "Frequent and regular scenario updates based on long-term monitoring") which was ranked higher by participants of Malagasy origin than those of other nationalities (Table S4b). We could not detect any differences in the ranking of knowledge gaps for different age groups (Table S4c, Figure S1c).

\subsection{Additional Knowledge Gaps Suggested by Participants}

For each knowledge gap category, the participants were given the option to list additional knowledge gaps which they considered of greater importance than those they gave the highest-ranking score. About one third of the participants used this option. Only one entirely new knowledge gap was listed as an ecological as well as a socio-economic knowledge gap by three participants: the impacts of climate change-driven human migration from southwestern to western Madagascar on socio-economic problems and its impacts on natural resources.

\section{Discussion}

The background information provided by our 51 experts demonstrates that they qualified as such given their backgrounds including work experience. The experts' backgrounds also shows that our sourced experts cover a wide range of positions and institutions so that bias towards interests of a particular group of researchers or decision makers is unlikely. Our top 10 list of key knowledge gaps addresses knowledge gaps from all three spheres of sustainability consisting of three ecological, three socio-economic knowledge gaps, four political, as well as two general knowledge gaps. None of the identified top 10 knowledge gaps was directly related to SDG 2 (Reduce Hunger), only four to SDG 10 (Reduce inequality) and three to SDG 15 (Life on Land). In the following paragraphs, we will first discuss the top 10 knowledge gaps by linking them to all SDGs, ABTs and the $2{ }^{\circ} \mathrm{C}$ target of the Paris Climate Agreement and then show recent local or larger scale attempts starting to address these knowledge gaps. Acknowledging the implications of our study and its limitations, we will provide suggestions for further work.

\subsection{Top 10 Knowledge Gaps}

The first two overall top priority knowledge gaps address the need to find "strategies to improve justice, fairness, enforcement of laws/rules" and to "gain more knowledge about the role of corruption as well as how to reduce it". Both knowledge gaps are strongly linked to another knowledge gap in the top 10 ranking: "Strategies to improve security from violence/theft/corruption" (rank 5). All three are addressed in SDG 16-one of the nine SDGs Madagascar failed to achieve according to the Africa SDG Index and Dashboard Report 2018 [45]. The issue of justice and fairness is also related to SDG 10 (Reduced inequalities), yet for African countries, no metrics exist for the achievement of this SDG [45]. So far, the issue of corruption has been completely lacking from the ABTs [15]. Lack of law enforcement, Zebu cattle theft and burglaries remain important issues for the rural population and the attempts to reduce corruption via an Anti-corruption Commission in 2002, Anti-Corruption Agency in 2004, or a governmental decree to ban illegal logging in 2005 have not helped to significantly reduce illegal activities $[39,90]$. Achieving better law/rule enforcement and fighting corruption is difficult as politicians, higher officials and local elites are often themselves involved in bribery or put no efforts in law enforcement for monetary, social or other benefits [91-94]. Corruption considerably undermines the protection of nature [95] as it reduces law enforcement and investments by international conservation agencies $[91,95]$. Since poor people often rely on the extraction of resources from protected areas to secure protein supply or to cover other subsistence needs, conservation laws and rules are often perceived as unfair and have been internationally criticized as "green-grabbing" [23,96,97]. This issue 
is addressed in the socio-economic knowledge gap "Economic benefits for local small-holder farmers from biodiversity" ranking 4 th overall (see further below).

Internationally, the most well-known type of corruption in Madagascar is probably associated with the illegal trade of precious wood species (particularly Dalbergia spp.) due to the involvement of politicians and international media attention. Madagascar's new president Andry Rajoelina who was elected in December 2018 promised to make the fight against corruption a priority [98]. However, given his past involvement in illegal rosewood trade, his agreement to reinstate the ban of rosewood trade that lacked any reinforcement [41], and government corruption levels which spiked under his de facto presidency between 2009 and 2013, many, particularly the international community, doubt his promise to curb corruption [99].

Since the illegal rosewood trade occurs predominantly in eastern Madagascar [100] and also because it is only one of many corruption issues, we deliberately included "corruption beyond logging" in this knowledge gap. Corruption affects all sorts of sectors, for example funds destined for education [101], the church [102], undermining of local land rights, and access associated with agribusinesses and mining operations [39]. Political instability and multiple political crises have resulted in difficulties to establish or monitor new policies [54]. This has been accompanied by an increase in deforestation for agriculture [63] as well as in other types of illegal resource exploitation [33,42,69,100]. Those trying to fight corruption (e.g., local forest guards, environmental groups, members of watchdog organizations, researchers) live dangerous lives as they have to fear being evicted as "rebellions" or being confronted with death threats to them and their family members [96,103].

Corruption indicators used to evaluate the SDG 16 (e.g., number of victims of intentional homicide, conflict-related deaths per 100,000 population, proportion of children who experienced any physical punishment and/or psychological aggression) lack many of the above described components of corruption issues in Madagascar [104]. The International Corruption Perception Index relies on experts' opinions regarding transparency, accountability and corruption in the public sector [44], even though Transparency International experts are mainly business people who seem ill-suited to represent locally affected residents. Involving the local communities via questionnaires or interviews as done by Gore et al. (2013) for a different conservation area in Madagascar would give a better understanding of the "hotspots" of corruption activities and thus easier ways to tackle these issues right where they occur. More general strategies to fight corruption would be fair wages, stringent accounting procedures and management partnerships [95]. Media coverage of corruption activities and the work of brave activists to fight them may also be helpful [101], as is pressure from the international community [91].

The highest ranking ecological knowledge gap (third highest overall rank) directly addresses the need to know more about appropriate restoration beneficial to the protection and sustainable use of biodiversity. Restoration is key to providing essential ecosystem services (ABT 14) and has been given increased attention by the Global Partnership for Forest Restoration and the Bonn Challenge (e.g., Ockenden et al. 2018). Ecosystem restoration and resilience is explicitly mentioned in ABT 15, but not in the targets of SDG 15. It is linked to SDG 12 and ABTs 4 and 7 due its consequences for sustainable production in terms of most sustainable reforestation methods. Technological advances (Perring et al. 2015), green finance options (FAO and Global Mechanism of the UNCD, 2015) and compensation measures, particularly in regards to telecoupling effects, can all support restoration activities (e.g., Ockenden et al. 2018). Restoration projects require long-term efforts of monitoring as well as associated adjustments to effectively protect biodiversity and enable sustainable use of resources within restored areas. Given that some species will be unable to cope with even slight anthropogenic disturbance, some restoration areas, particularly corridors enabling migration between remaining habitat patches, will have to meet the needs of these sensitive species. Other restoration areas allowing for human resource utilization may still provide habitats for a number of less sensitive species. "Strategies to secure long-term funding" (rank 6) will be necessary to ensure that restoration will be sustainable. 
If wisely done, reforestation can be extremely beneficial for biodiversity by providing suitable habitat connected by corridors or stepping stones $[105,106]$. Madagascar committed to the Bonn Challenge to reforest four million hectares of forest, but little progress has been made and the benefits only address the economy and climate $[40,107]$. Madagascar's National Biodiversity Strategy and Action Plan (NBSAP) lists restoration of at least 15\% degraded habitats as one of its five strategic goals (Objective 15 in [108], p. 89). As a solution it mentions agro-ecological techniques as "effective tools for the degraded vegetation" but does not provide any details on what these tools to restore degraded vegetation are. Similarly, "appropriate strategies are set up to safeguard these ecosystems [ ... ] for human well-being especially local communities through restoration activities" are mentioned, but actual strategies on how this can be achieved are only vaguely mentioned: "Tools or Handbook of conservation and/or Ecological restoration of various existing tropical forest types are developed" [ibid.] (p. 106) and "Number of recovery programs for protected areas of degraded ecosystems is developed and implemented" [ibid.] (p. 114). The knowledge gap concerning appropriate restoration strategies is also linked to SDG 13 and the $2{ }^{\circ} \mathrm{C}$ target of the Paris Climate Agreement as restoration will help mitigate climate change due to increased carbon storage, a decreased albedo and associated effects caused by revegetation measures $[105,109,110]$.

The socio-economic knowledge gap considered most important (overall rank 4), "Economic benefits for local small-holder farmers from biodiversity", is directly related to SDG 8 (Decent work) in combination with the protection of biodiversity (SDG 15, ABT 11) and ecosystem services (ABT 14) and explicitly addressed as important in Madagascar's NBSAP [Objective 2 in 108] (p. 70f). Herein, it has been acknowledged that a fair distribution of benefits of ecosystem services requires more research, and where payment schemes for ecosystem services have been successful these approaches should be used as a guideline and adjusted to local contexts [65,111-113]. To date, most of these payments never covered the opportunity costs locals had to endure for the conservation of biodiversity, patrols were reluctant to convict fellow community members of illegal actions, and positive trends were reported although forest degradation actually increased $[111,114,115]$.

Payments for ecosystem services like those within the REDD program (Reduced Emissions from Deforestation and Forest Degradation) can only be successful under certain conditions [115]. MacKinnon et al. (2017) reported that the amount of money reaching a community differed strongly between methods and that projects directly compensating for the loss of forest resources (e.g., by fish farming or bee keeping) were the most successful. Anticipated and promoted benefits for local people through tourism [69] rarely materialized $[48,116]$, although there have been some cases of livelihood benefits from eco-tourism in a few tourism hotspots [114]. However, usually these benefited only a few people and not whole communities [102,117].

More knowledge regarding "strategies to improve security from violence/theft/corruption" has been the fifth highest ranking knowledge gap. This comes as no surprise, as Malagasy people have also ranked crime and insecurity as top priority issues for the government [118]. This knowledge gap concerns aspects of inequality (SDG 10) as poor people are most affected by these issues, but also to SDG 16 as strong institutions are necessary to tackle these issues. To avoid cattle theft, which is considered as "extremely worrisome" [119] cattle are kept hidden in forests, which promotes forest degradation and hampers forest regeneration [39]. People who have no choice but to continue to use forest resources for their survival also fear violence and fines from forest police [119]. Since law enforcement is largely lacking, laws are no deterrent for committing crimes in Madagascar, but an increase in law enforcement personnel locally and at least temporally decreases cattle theft (see [120] and references therein). Residents from villages with missions, police or military presence feel safer [119]. However, in remote areas, governmental control is particularly weak (or even completely lacking) [103]. While cattle theft is usually practiced by well-organized groups which cooperate with local authorities, burglaries and crop theft are rather associated with poverty and hunger of the rural poor as a coping strategy under high survival risk [120]. 
"Identification of strategies to improve long-term funding" has been identified as the 6th highest ranking knowledge gap and relates to all four spheres of sustainability [82]. Limited and short-term funding have been impeding long-term monitoring and successful participatory strategies [119]. Securing long-term funding for research, environmental as well as human aid projects is a global problem which is why this issue is picked up in ABT 20 (Mobilizing resources from all sources). It is strongly tied to the issue of short election cycles, awareness of the benefits of long-term funding instead of funding invested in many short-term projects and an issue of changes in staff when running long-term projects.

We combined the aspects of appropriate livestock management (here zebu cattle farming) and fire regimes in one knowledge gap (see Table 1, rank 7) as both have experienced little research and both are closely interrelated: grasslands, woodlands and forests are burnt to provide fresh pastures for zebu cattle and even where fire is not deliberately set, these pasture fires often escape unintentionally and burn adjacent habitats [39,121-123]. This knowledge gap is linked to the protection of biodiversity (SDG 15, ABT 7), sustainable management (SDG 12, ABT 4 and 7) and also to climate change (SDG 13, $2{ }^{\circ} \mathrm{C}$ target) as fire and cattle farming increase atmospheric $\mathrm{CO}_{2}$-levels. Research needs for "appropriate management of livestock and fire regimes" are only partly addressed in Madagascar's National Biodiversity Strategy and Action Plan [108]: "programs aimed at strengthening the control of bush fires" and those that minimize fire impacts in areas with significant biodiversity by creating effective buffer zones around protected areas and more training of fire extinguishing personnel are explicitly mentioned [ibid.] (p. 107). Appropriate and more sustainable livestock management are not addressed though, indicating that this issue has not even gained due attention.

Zebu farming has a negligible role as a protein source, but cattle have important cultural value (slaughtered for special cultural occasions) and herd size indicates social status [39,122,124]. Zebu cattle are also used for agricultural labor and transport [125] and as an insurance asset to buffer income loss during times of hardship like droughts or low crop market prices [119,122,126]. The cultural importance of zebu cattle is particularly high for temporary Antandroy migrants from the south who use slash-and-burn agriculture for cash crops (particularly corn) to purchase cattle and thus increase their social status when returning home [119,125]. Climate change has already induced higher frequency and intensity of droughts in southern Madagascar which has led to increased migration of Antandroy from southern Madagascar into central western Madagascar severely increasing the pressure on the dry forests $[39,122]$. Traders involved in illegal corn and peanut plantation farms actively lure these migrants in for illegally clearing the forests for them by promising them quick and easy payment for each hectare of forest cleared as well as covering their travel and accommodation costs [127]. This climate change-induced migration issue has been the only additional knowledge gap suggested by several experts in our study. We agree that more knowledge about this issue and strategies to mitigate it via prosecution of and high fines for traffickers have a very high priority and that it should be on the priority list of current decision makers [40].

The third highest ranking ecological knowledge gap (overall rank 8) concerned ecosystem services at risk from slash-and-burn farming. Like the previous ecological knowledge gap concerning livestock and fire management, it is linked to biodiversity (SDG 15, ABT 7) and ecosystem service loss (ABT 14), as well as to consequences of fire on $\mathrm{CO}_{2}$-levels and hence climate change (SDG 13, $2{ }^{\circ} \mathrm{C}$ target). We principally know that dry forests provide essential ecosystem services and that these are at risk from slash-and-burn farming but ranking this knowledge gap so high indicates that our understanding of which ecosystem services are affected with what potential cascading consequences is not yet perceived as being sufficient. Madagascar's NBSAP is strongly committed to ensure future provisioning of ecosystem services through the protection of $10 \%$ of terrestrial ecosystems, sustainable management (including certification), sustainable tourism, compensation activities like restoration, as well as additional studies to develop and implement appropriate strategies [108].

This knowledge gap has direct consequences for the sociological knowledge gap concerning the effectiveness of education and awareness-raising on biodiversity conservation linked to SDG 4 
(Quality education) and ABT 1 (Awareness of biodiversity has increased). People who understand the implications of their actions are less likely to undertake them if they anticipate negative consequences for themselves or their families. Creating this understanding is particularly difficult when the effects of actions are complex and only visible in the more distant future. Better education may increase chances of income diversification [128] and improve community forest management [113]. Both, education and awareness raising are essential for the protection of biodiversity as they can lead to more understanding of ecosystem services nature provides [129]. For example, Reibelt, et al. [130] have shown that in south-western Madagascar, awareness of local people rises through direct contact with endangered species on which they rely for subsistence.

One of the two knowledge gaps at rank 9 concerns the improvement of sustainable methods by "more frequent and regular scenario-updates based on long-term monitoring". This general knowledge gap is of course directly related to the protection of biodiversity (SDG 15, ABT 7). Building the necessary trust for participatory approaches, negotiating rules and calculating long-term costs and benefits of biodiversity loss are all time-consuming activities. The efforts required for collecting solid data at realistic temporal scales need to be considered in biodiversity strategies and action plans (ABT 17). We considered this knowledge gap to be a general one as long-term monitoring for more frequent and regular scenario updates is also important in socio-economic and political planning, like long-term costs and successes of education programs (SDG 4) or the effectiveness of PES on political decisions.

Demonstrating how interrelated our identified key knowledge gaps are, the knowledge gap concerning appropriate strategies for restoration (overall rank 3) also relies on long-term monitoring-which again depends on long-term funding (rank 6), and consequently they all are strongly linked to ABT 20 ("Mobilizing resources from all sources").

The other knowledge gap at rank 9 "Traditional knowledge about sustainable natural resource use" belongs to the socio-economic sphere of sustainability and is directly linked to ABT 18 (Traditional knowledge): "In 2015, the initiatives put in place to protect traditional knowledge, innovations and practices of local communities relevant to biodiversity. The traditional sustainable use of biodiversity and their contribution to conservation are respected, preserved and maintained" which has been given funding priority by Madagascar's NBSAP when compared to restoration (Objective 15) and the evaluation of ecosystem services for PES schemes (Objective 2) (both in [108], (p. 154f)).

We need to become aware of traditional knowledge before it will be lost and to find out how traditional conservation values overlap with those of scientists [131]. Local people's knowledge has been shown to provide important insights for sustainable land management and use of resources in south-western Madagascar [132]. Several authors have shown that to achieve effective conservation in Madagascar, every ethnic group should be integrated from the start $[133,134]$. More use should be made of existing forms of traditional, local agreements and institutions, because such local rules are generally more adhered to $[133,135]$.

The lowest ranking knowledge gap within our top 10 list "Interdisciplinary work to generate most comprehensive data sets" is strongly linked with the higher-ranking ones. It is in some ways addressed in SDG 17 (Partnerships of the goals) and ABT 19 (Sharing information and knowledge) as well as ABT 20 (Mobilizing resources from all sources). In 2015, the journal Nature dedicated a special issue on the topic of interdisciplinarity demonstrating why "scientists must work together to save the world" [136]. However, interdisciplinarity should go beyond that of scientists and-in a transdisciplinary way-include knowledge from other sources like that of local/indigenous people or organizations with long-term on the ground experiences. Interdisciplinary work has been considered particularly important for studying the ecological impacts of climate change [137]. Finding ways to deal with environmental challenges associated with such impacts and their consequences for human well-being requires incorporating social and human-centered approaches by using participatory approaches [ibid.].

Most knowledge gaps which focused on generating more data within their own discipline received the lowest mean scores (Table S3), potentially indicating that our experts consider it more important to 
make use of existing data by using it in an interdisciplinary way than investing money into research of deficient, but highly specific research fields. A focus on improving decision-making and a call for more action rather than further investment in data collection has also been proposed by others [138]. However, we agree with Stuart et al. [139] that investing into more data generation, particularly those concerning threatened and data deficient species, remains important for conducting appropriate actions and adjusting management strategies as needed.

\subsection{Effects of Different Expert Backgrounds on Ranking Scores}

Our study showed that our top 10 list of key knowledge gaps would not have differed, would we have conducted this study without experts from other countries, only with women or only with experts of a certain age group, except for the knowledge gap concerning frequent and regular scenario updates which was considered of higher importance by Malagasy than other nationalities (Table S4, Figure S1b). Given the influence of place attachment, gender and age on the judgement of conservation related issues which has been pointed out by others [86], we are pleased about predominantly Malagasy experts ranking our knowledge gaps, about the relatively even gender ratio and that the bulk of our experts were medium and older aged and had long working experience in the area.

\subsection{Limitations, Implications and Recommendations for Future Work}

We are aware of the limitations of this study. To keep the questionnaire short, some knowledge gaps were already combined. Ideally, knowledge gaps should be kept separate and maybe in addition also presented in combination to give participants the option to score whether they found the combination more important than its parts. We tried to accommodate for this by giving the opportunity to express this in the comments sections or by listing additional highest priority knowledge gaps. Network sampling of experts as well as expert consultations in a relatively short time frame, which are typical for many projects, always have limitations as they are rarely comprehensive [84]. Our questionnaires were in English; future studies should include versions in French and potentially even Malagasy to be more inclusive. For other case studies, particularly those with more time and resources as well as those with a narrower, i.e., local focus, we recommend involving experts as well as local people right from the beginning, i.e., when the questions to be ranked are gathered [21]. To avoid translation problems when involving local people, highly skilled translators will be necessary. These need to be trained not only in translating western conservation ideas into local language and values, but also and most likely more importantly, the locals' values, beliefs and proverbs into concepts that can be integrated into conservation policy [116]. Even participatory approaches involving community members cannot claim to be the gold standard [140]. Since not every community member can be involved, participation is usually only possible for high ranking representatives of communities. These are usually elderly men so that a gender and age bias in selecting key knowledge gaps may become an issue. However, we agree that, given more time and resources, a Delphi-like process (i.e., at least two rounds of questionnaires, each accompanied by accumulation of responses and anonymous feedback to participants) should be used to prioritize knowledge gaps [21]. Ideally, representatives of local communities should be involved, particularly when attempting knowledge gap prioritization at a local level. We tried to accommodate for the lack of expert engagement from the start by providing an option to list additional knowledge gaps. We also acknowledge that the number of participants was relatively low and dominated by academics due to the networks of the authors. Despite those limitations, we hope that our work substantially contributes to pinpointing the most urgent knowledge gaps which need to be addressed to secure local livelihoods and better protect biodiversity in the dry forests of western Madagascar-and hence better achieve the SDGs, ABTs and the $2{ }^{\circ} \mathrm{C}$ target of the Paris Climate Agreement. Our priority list of knowledge gaps should be considered a first attempt of identifying most urgent research needs and help funding bodies to streamline investments at the regional level (i.e., the dry forests of western Madagascar). Like the global research questions identified for example by Oldekopp et al. (2016), the knowledge gaps identified for the slash-and-burn problematic in western 
Madagascar can be used at a regional level as a starting point for research project designs, collaborations and debates between academics, practitioners, politicians and stakeholders.

\section{Conclusions}

In our study on the identification of priority knowledge gaps to better protect biodiversity and simultaneously secure local livelihoods, we focused on the loss of dry forests by subsistence agriculture in western Madagascar. However, we are aware that large international agribusinesses and the mining industry, as well as oil extraction practices, may locally present a bigger threat to this biome than slash-and-burn farming [39], particularly seeing how these industries has wiped forests from other countries like for example Ghana [141]. It is of great concern that Madagascar's president Andry Rajoelina's recently announced cabinet mainly consists of technicians and business leaders [98] and that he declared to follow Ghana in its recent advances in economic development [142]. Conservationists are highly concerned about his priority of short-term economic gains over long-term security of natural resources and ecosystem services $[99,143,144]$. Scientists including ourselves therefore call on the new president to keep to his promise aiming to curb corruption and to make Madagascar a model for conservation, while simultaneously urging the international community to continue its financial support of protecting biodiversity in Madagascar [40,143,145-147].

Not surprisingly given the interlinkages of the goals and targets of the SDGs, ABTs and $2{ }^{\circ} \mathrm{C}$ target of the Paris Climate Agreement [10,12,78], the results of our study demonstrate that even though we started with a focus on SDGs 2, 10 and 15, the priority knowledge gaps identified concern a wide range of other SDGs and address issues necessary to be solved to better reach several ABTs as well as the $2{ }^{\circ} \mathrm{C}$ target.

Many characteristics of the problems and challenges found in Madagascar are comparable to those in other biodiversity-rich but economically disadvantaged countries [33]. We hope that our idea of focusing the search for key knowledge gaps on a regional scale (i.e., the dry forests of western Madagascar) and using expert involvement via questionnaires can be used as a blue-print, inspiring and aligning most urgent research projects, streamlining research funds and resources to local needs.

Supplementary Materials: The following are available online at http://www.mdpi.com/2071-1050/11/20/5695/s1: Questionnaire S1, Table S2: Background information of participating experts, Table S3: Complete ranking of all knowledge gaps, Table S4: Knowledge gaps rankings compared between (a) female and male participants, (b) Malagasy participants and those of other nationality, and (c) different age groups, Table S5: Full list of participants' suggested additional knowledge gaps, Figure S1. Differences in mean ranking scores by (a) female and male participants, (b) participants of Malagasy origin and those of other nationalities, and (c) participants of young $(<25,25-35)$, medium (35-45) and older $(45-65,>65)$ age.

Author Contributions: Conceptualization: A.S.K.F. and L.S., data curation: A.S.K.F.; Formal analysis: A.S.K.F.; funding acquisition: L.S.; investigation: L.S., A.S.K.F.; methodology: A.S.K.F. and L.S.; project administration: L.S.; resources: L.S.; supervision: L.S.; writing—original draft preparation: A.S.K.F., L.S.; writing—review and editing: A.S.K.F. and L.S.

Funding: This research was conducted within the project "Towards a future sustainable world where climate, biodiversity and human well-being are safeguarded" (sustainCBW)", funded by the Leibniz Association (grant number SAS-2017-PIK-LFV) and the Zoological Research Museum Alexander Koenig.

Acknowledgments: We thank the sustainCBW project partners Kirsten Thonicke and Diana Sietz (Potsdam Institute for Climate Impact Research), Katrin Vohland and Jens Jetzkowitz (Museum für Naturkunde Berlin), Ana Paula Aguiar and Odirilwe Selomane (Stockholm Resilience Centre), Carolin Sperk (Think Tank for Sustainability, Berlin) for valuable comments in the initial phase of this project and Wolfgang Wägele (Zoological Research Museum Alexander Koenig, Bonn) for logistic support. Particular thanks go to Peter Kappeler, Christian Roos and Matthias Markolf (German Primate Center, Göttingen) who helped pilot trialing the questionnaire. Matthias Markolf also helped us spreading the questionnaires through his networks. We would also like to thank all the participating experts in this study for their time and effort to fill in our questionnaire, and our three anonymous reviewers whose comments and suggestions significantly improved an earlier version of this manuscript.

Conflicts of Interest: The authors declare no conflict of interest. 


\section{References}

1. UN General Assembly. Transforming our World: The 2030 Agenda for Sustainable Development. Available online: http://www.refworld.org/docid/57b6e3e44.htm (accessed on 27 June 2018).

2. Secretariat of the Convention on Biological Diversity. Strategic Plan for Biodiversity 2011-2020 and the Aichi Targets Living in Harmony with Nature. Available online: http://www.cbd.int/doc/strategic-plan/2011-2020/ Aichi-Targets-EN.pdf (accessed on 27 June 2018).

3. United Nations. The Paris Agreement. Available online: https://unfccc.int/resource/docs/2015/cop21/eng/ 109r01.pdf (accessed on 27 June 2018).

4. Naeem, S.; Chazdon, R.; Duffy, J.E.; Prager, C.; Worm, B. Biodiversity and human well-being: An essential link for sustainable development. Proc. R. Soc. B Biol. Sci. 2016, 283. [CrossRef] [PubMed]

5. Bennett, E.M.; Cramer, W.; Begossi, A.; Cundill, G.; Díaz, S.; Egoh, B.N.; Geijzendorffer, I.R.; Krug, C.B.; Lavorel, S.; Lazos, E.; et al. Linking biodiversity, ecosystem services, and human well-being: Three challenges for designing research for sustainability. Curr. Opin. Environ. Sustain. 2015, 14, 76-85. [CrossRef]

6. Chen, Y.; Peng, S. Evidence and mapping of extinction debts for global forest-dwelling reptiles, amphibians and mammals. Sci. Rep. 2017, 7, 44305. [CrossRef] [PubMed]

7. Butchart, S.H.M.; Walpole, M.; Collen, B.; van Strien, A.; Scharlemann, J.P.W.; Almond, R.E.A.; Baillie, J.E.M.; Bomhard, B.; Brown, C.; Bruno, J.; et al. Global Biodiversity: Indicators of Recent Declines. Science 2010, 328, 1164-1168. [CrossRef]

8. Ceballos, G.; Ehrlich, P.R.; Barnosky, A.D.; García, A.; Pringle, R.M.; Palmer, T.M. Accelerated modern human-induced species losses: Entering the sixth mass extinction. Sci. Adv. 2015, 1. [CrossRef]

9. TEEB. TEEB for Agriculture \& Food: An Interim Report; United Nations Environment Programme: Geneva, Switzerland, 2015.

10. Le Blanc, D. Towards integration at last? The sustainable development goals as a network of targets. Sustain. Dev. 2015, 23, 176-187. [CrossRef]

11. Nilsson, M.; Griggs, D.; Visbeck, M. Policy: Map the interactions between Sustainable Development Goals. Nat. News 2016, 534, 320. [CrossRef]

12. Schultz, M.; Tyrrell, T.; Ebenhard, T. The 2030 Agenda and Ecosystems-A Discussion Paper on the Links between Aichi Biodiversity Targets and the Sustainable Development Goals; SwedBio at Stockholm Resilience Centre: Stockholm, Sweden, 2016.

13. Spangenberg, J.H. Hot air or comprehensive progress? A critical assessment of the SDGs. Sustain. Dev. 2017, 25, 311-321. [CrossRef]

14. Stafford-Smith, M.; Griggs, D.; Gaffney, O.; Ullah, F.; Reyers, B.; Kanie, N.; Stigson, B.; Shrivastava, P.; Leach, M.; O'Connell, D. Integration: The key to implementing the Sustainable Development Goals. Sustain. Sci. 2017, 12, 911-919. [CrossRef]

15. Driscoll, D.A.; Bland, L.M.; Bryan, B.A.; Newsome, T.M.; Nicholson, E.; Ritchie, E.G.; Doherty, T.S. A biodiversity-crisis hierarchy to evaluate and refine conservation indicators. Nat. Ecol. Evol. 2018, 2, 775-781. [CrossRef]

16. Di Marco, M.; Chapman, S.; Althor, G.; Kearney, S.; Besancon, C.; Butt, N.; Maina, J.M.; Possingham, H.P.; Rogalla von Bieberstein, K.; Venter, O.; et al. Changing trends and persisting biases in three decades of conservation science. Glob. Ecol. Conserv. 2017, 10, 32-42. [CrossRef]

17. Global Policy Watch. Desperately Seeking Indicators. Available online: https://www.globalpolicywatch.org/ blog/2018/11/01/desperately-seeking-indicators/ (accessed on 13 April 2019).

18. Schmidt-Traub, G.; Kroll, C.; Teksoz, K.; Durand-Delacre, D.; Sachs, J.D. National baselines for the Sustainable Development Goals assessed in the SDG Index and Dashboards. Nat. Geosci. 2017, 10, 547. [CrossRef]

19. Joppa, L.N.; O'Connor, B.; Visconti, P.; Smith, C.; Geldmann, J.; Hoffmann, M.; Watson, J.E.M.; Butchart, S.H.M.; Virah-Sawmy, M.; Halpern, B.S.; et al. Filling in biodiversity threat gaps. Science 2016, 352, 416-418. [CrossRef]

20. Shackleton, R.T.; Angelstam, P.; van der Waal, B.; Elbakidze, M. Progress made in managing and valuing ecosystem services: A horizon scan of gaps in research, management and governance. Ecosyst. Serv. 2017, 27, 232-241. [CrossRef]

21. Sutherland, W.J.; Adams, W.M.; Aronson, R.B.; Aveling, R.; Blackburn, T.M.; Broad, S.; Ceballos, G.; Côte, I.M.; Cowling, R.M.; Da Fonseca, G.A.B.; et al. One Hundred Questions of Importance to the Conservation of Global Biological Diversity. Conserv. Biol. 2009, 23, 557-567. [CrossRef] 
22. Convention on Biological Diversity. United Nations Decade on Biodiversity. Available online: www.cbd.int/ 2011-2020/ (accessed on 30 April 2019).

23. Fairhead, J.; Leach, M.; Scoones, I. Green Grabbing: A new appropriation of nature? J. Peasant Stud. 2012, 39, 237-261. [CrossRef]

24. Oldekop, J.A.; Holmes, G.; Harris, W.E.; Evans, K.L. A global assessment of the social and conservation outcomes of protected areas. Conserv. Biol. 2016, 30, 133-141. [CrossRef]

25. Dudley, N.; Jonas, H.; Nelson, F.; Parrish, J.; Pyhälä, A.; Stolton, S.; Watson, J.E.M. The essential role of other effective area-based conservation measures in achieving big bold conservation targets. Glob. Ecol. Conserv. 2018, 15, e00424. [CrossRef]

26. Adams, W.M.; Aveling, R.; Brockington, D.; Dickson, B.; Elliott, J.; Hutton, J.; Roe, D.; Vira, B.; Wolmer, W. Biodiversity Conservation and the Eradication of Poverty. Science 2004, 306, 1146-1149. [CrossRef]

27. Andam, K.S.; Ferraro, P.J.; Sims, K.R.E.; Healy, A.; Holland, M.B. Protected areas reduced poverty in Costa Rica and Thailand. Proc. Natl. Acad. Sci. USA 2010, 107, 9996-10001. [CrossRef]

28. Kashwan, P. Inequality, democracy, and the environment: A cross-national analysis. Ecol. Econ. 2017, 131, 139-151. [CrossRef]

29. Holland, T.G.; Peterson, G.D.; Gonzalez, A. A cross-national analysis of how economic inequality predicts biodiversity loss. Conserv. Biol. 2009, 23, 1304-1313. [CrossRef] [PubMed]

30. Hicks, C.C.; Levine, A.; Agrawal, A.; Basurto, X.; Breslow, S.J.; Carothers, C.; Charnley, S.; Coulthard, S.; Dolsak, N.; Donatuto, J.; et al. Engage key social concepts for sustainability. Science 2016, 352, 38-40. [CrossRef] [PubMed]

31. Biedenweg, K.; Gross-Camp, N.D. A brave new world: Integrating well-being and conservation. Ecol. Soc. 2018, 23. [CrossRef]

32. Tabor, K.; Hewson, J.; Tien, H.; González-Roglich, M.; Hole, D.; Williams, J. Tropical Protected Areas Under Increasing Threats from Climate Change and Deforestation. Land 2018, 7, 90. [CrossRef]

33. Waeber, P.O.; Wilmé, L.; Mercier, J.-R.; Camara, C.; Lowry, P.P., II. How Effective Have Thirty Years of Internationally Driven Conservation and Development Efforts Been in Madagascar? PLoS ONE 2016, 11, e0161115. [CrossRef]

34. World Bank. Madagascar: Poverty Assessment; World Bank: Washington, DC, USA, 1996; Available online: http://documents.worldbank.org/curated/en/docsearch/report/14044 (accessed on 12 September 2019).

35. Selomane, O.; Reyers, B.; Biggs, R.; Tallis, H.; Polasky, S. Towards integrated social-ecological sustainability indicators: Exploring the contribution and gaps in existing global data. Ecol. Econ. 2015, 118, 140-146. [CrossRef]

36. Ploch, L.; Cook, N. Madagascar's Political Crisis; U.S. Congressional Research Service: Washington, DC, USA, 2012; Available online: http://www.fas.org/sgp/crs/row/R40448.pdf (accessed on 18 November 2018).

37. Hänke, H.; Barkmann, J.; Coral, C.; Kaustky, E.E.; Marggraf, R. Social-ecological traps hinder rural development in southwestern Madagascar. Ecol. Soc. 2017, 22. [CrossRef]

38. World Bank. ID4D Country Diagnostic: Madagascar; World Bank: Washington, DC, USA, 2017; Available online: http://pubdocs.worldbank.org/en/809191510763351833/Madagascar-ID4D-IMSA.pdf (accessed on 18 November 2018).

39. Waeber, P.O.; Wilmé, L.; Ramamonjisoa, B.; Garcia, C.; Rakotomalala, D.; Rabemananjara, Z.H.; Kull, C.A.; Ganzhorn, J.U.; Sorg, J.P. Dry forests in Madagascar: Neglected and under pressure. Int. For. Rev. 2015, 17, 127-148. [CrossRef]

40. Jones, J.P.G.; Ratsimbazafy, J.; Ratsifandrihamanana, A.N.; Watson, J.E.M.; Andrianandrasana, H.T.; Cabeza, M.; Cinner, J.E.; Goodman, S.M.; Hawkins, F.; Mittermeier, R.A.; et al. Last chance for Madagascar's biodiversity. Nat. Sustain. 2019, 2, 350-352. [CrossRef]

41. Innes, J.L. Madagascar rosewood, illegal logging and the tropical timber trade. Madag. Conserv. Dev. 2010, 5, 6-10. [CrossRef]

42. Randriamalala, H.; Liu, Z. Rosewood of Madagascar: Between democracy and conservation. Madag. Conserv. Dev. 2010, 5, 12. [CrossRef]

43. Institute for Economics \& Peace. Global Peace Index 2018: Measuring Peace in a Complex World; Sydney, Australia, 2018. Available online: http://visionofhumanity.org/reports (accessed on 7 November 2018).

44. Transparency International. Corruption Perceptions Index 2017. Available online: https://www.transparency. org/news/feature/corruption_perceptions_index_2017 (accessed on 13 April 2019). 
45. The Sustainable Development Goals Center for Africa and Sustainable Development Solutions Network. Africa SDG Index and Dashboards Report 2018; The Sustainable Development Goals Center for Africa and Sustainable Development Solutions Network: Kigali, Rwanda; New York, NY, USA, 2018.

46. Rasolofoson, R.A.; Nielsen, M.R.; Jones, J.P.G. The potential of the Global Person Generated Index for evaluating the perceived impacts of conservation interventions on subjective well-being. World Dev. 2018, 105, 107-118. [CrossRef]

47. Gardner, C.J.; Nicoll, M.E.; Birkinshaw, C.; Harris, A.; Lewis, R.E.; Rakotomalala, D.; Ratsifandrihamanana, A.N. The rapid expansion of Madagascar's protected area system. Biol. Conserv. 2018, 220, 29-36. [CrossRef]

48. Scales, I.R. The future of biodiversity conservation and environmental management in Madagascar: Lessons from the past and challenges ahead. In Conservation and Environmental Management in Madagascar; Routledge: London, UK, 2014; pp. 342-360.

49. Myers, N.; Mittermeier, R.A.; Mittermeier, C.G.; da Fonseca, G.A.B.; Kent, J. Biodiversity hotspots for conservation priorities. Nature 2000, 403, 853. [CrossRef] [PubMed]

50. Allnutt, T.F.; Asner, G.P.; Golden, C.D.; Powell, G.V.N. Mapping Recent Deforestation and Forest Disturbance in Northeastern Madagascar. Trop. Conserv. Sci. 2013, 6, 1-15. [CrossRef]

51. Razafimanahaka, J.H.; Jenkins, R.K.B.; Andriafidison, D.; Randrianandrianina, F.; Rakotomboavonjy, V.; Keane, A.; Jones, J.P.G. Novel approach for quantifying illegal bushmeat consumption reveals high consumption of protected species in Madagascar. Oryx 2012, 46, 584-592. [CrossRef]

52. Hockley, N.; Mandimbiniaina, R.; Rakotonarivo, O.S. Fair and equitable conservation: Do we really want it, and if so, do we know how to achieve it? Madag. Conserv. Dev. 2018, 13, 3-5. [CrossRef]

53. Scales, I.R. Farming at the Forest Frontier: Land Use and Landscape Change in Western Madagascar, 1896-2005. Environ. Hist. 2011, 17, 499-524. [CrossRef]

54. Stoudmann, N.; Waeber, P.O.; Randriamalala, I.H.; Garcia, C. Perception of change: Narratives and strategies of farmers in Madagascar. J. Rural Stud. 2017, 56, 76-86. [CrossRef]

55. Jarosz, L. Defining and Explaining Tropical Deforestation: Shifting Cultivation and Population Growth in Colonial Madagascar (1896-1940). Econ. Geogr. 1993, 69, 366-379. [CrossRef] [PubMed]

56. Ganzhorn, J.U.; Sorg, J.-P. Ecology and Economy of a Tropical Dry Forest in Madagascar; Deutsches Primatenzentrum: Göttingen, Germany, 1996.

57. Scales, I.R. The drivers of deforestation and the complexity of land use in Madagascar. In Conservation and Environmental Management in Madagascar; Routledge: London, UK, 2014; pp. 129-150.

58. Raharimalala, O.; Buttler, A.; Dirac Ramohavelo, C.; Razanaka, S.; Sorg, J.-P.; Gobat, J.-M. Soil-vegetation patterns in secondary slash and burn successions in Central Menabe, Madagascar. Agric. Ecosyst. Environ. 2010, 139, 150-158. [CrossRef]

59. Gay-des-Combes, J.M.; Robroek, B.J.M.; Hervé, D.; Guillaume, T.; Pistocchi, C.; Mills, R.T.E.; Buttler, A. Slash-and-burn agriculture and tropical cyclone activity in Madagascar: Implication for soil fertility dynamics and corn performance. Agric. Ecosyst. Environ. 2017, 239, 207-218. [CrossRef]

60. Ganzhorn, J.U.; Lowry, P.P.; Schatz, G.E.; Sommer, S. The biodiversity of Madagascar: One of the world's hottest hotspots on its way out. Oryx 2001, 35, 346-348. [CrossRef]

61. Reed, D.H. Impact of Climate Change on Biodiversity. In Handbook of Climate Change Mitigation and Adaptation; Chen, W.-Y., Suzuki, T., Lackner, M., Eds.; Springer: Berlin, Germany, 2017; pp. 595-620.

62. Hannah, L.; Dave, R.; Lowry, P.P.; Andelman, S.; Andrianarisata, M.; Andriamaro, L.; Cameron, A.; Hijmans, R.; Kremen, C.; MacKinnon, J.; et al. Climate change adaptation for conservation in Madagascar. Biol. Lett. 2008, 4, 590-594. [CrossRef]

63. Zinner, D.; Wygoda, C.; Razafimanantsoa, L.; Rasoloarison, R.; Andrianandrasana, H.T.; Ganzhorn, J.U.; Torkler, F. Analysis of deforestation patterns in the central Menabe, Madagascar, between 1973 and 2010. Reg. Environ. Chang. 2014, 14, 157-166. [CrossRef]

64. Mittermeier, R.A.; Myers, N.; Thomsen, J.B.; Da Fonseca, G.A.B.; Olivieri, S. Biodiversity Hotspots and Major Tropical Wilderness Areas: Approaches to setting conservation priorities. Conserv. Biol. 1998, 12, 516-520. [CrossRef]

65. Sommerville, M.; Jones, J.P.; Rahajaharison, M.; Milner-Gulland, E. The role of fairness and benefit distribution in community-based Payment for Environmental Services interventions: A case study from Menabe, Madagascar. Ecol. Econ. 2010, 69, 1262-1271. [CrossRef] 
66. Schäffler, L.; Kappeler, P.M. Distribution and Abundance of the World's Smallest Primate, Microcebus berthae, in Central Western Madagascar. Int. J. Primatol. 2014, 35, 557-572. [CrossRef]

67. Ganzhorn, J.U.; Sommer, S.; Abraham, J.P.; Ade, M.; Raharivololona, B.M.; Rakotovao, E.R.; Rakotondrasoa, C.; Randriamarosoa, R. Mammals of the Kirindy Forest with special emphasis on Hypogeomys antimena and the effects of logging on the small mammal fauna. In Ecology and Economy of a Tropical Dry Forest in Madagascar. Primate Report, 46-1; Ganzhorn, J.U., Sorg, J.-P., Eds.; German Primate Center: Göttingen, Germany, 1996; pp. 215-232.

68. Bloxam, Q.M.C.; Behler, J.L.; Rakotovao, E.R.; Randriamahazo, H.J.A.R.; Hayes, K.T.; Tonge, S.J.; Ganzhom, J.U. Effects of logging on the reptile fauna of the Kirindy Forest with special emphasis on the flat-tailed tortoise (Pyxis planicauda). In Ecology and Economy of a Tropical Dry Forest in Madagascar. Primate Report, 46-1; Ganzhorn, J.U., Sorg, J.-P., Eds.; German Primate Center: Göttingen, Germany, 1996.

69. Schwitzer, C.; Mittermeier, R.A.; Johnson, S.E.; Donati, G.; Irwin, M.; Peacock, H.; Ratsimbazafy, J.; Razafindramanana, J.; Louis, E.E.; Chikhi, L.; et al. Averting Lemur Extinctions amid Madagascar's Political Crisis. Science 2014, 343, 842-843. [CrossRef]

70. Schäffler, L.; Saborowski, J.; Kappeler, P.M. Agent-mediated spatial storage effect in heterogeneous habitat stabilizes competitive mouse lemur coexistence in Menabe Central, Western Madagascar. BMC Ecol. 2015, 15, 7. [CrossRef] [PubMed]

71. Ganzhorn, J.U.; Fietz, J.; Rakotovao, E.; Schwab, D.; Zinner, D. Lemurs and the regeneration of dry deciduous forest in Madagascar. Conserv. Biol. 1999, 13, 794-804. [CrossRef]

72. Olson, D.M.; Dinerstein, E. The Global 200: Priority ecoregions for global conservation. Ann. Mo. Bot. Garden 2002, 89, 199-224. [CrossRef]

73. Langhammer, P.F.; Bakarr, M.I.; Bennun, L.; Brooks, T.M. Identification and Gap Analysis of Key Biodiversity Areas: Targets for Comprehensive Protected Area Systems; IUCN: Gland, Switzerland, 2007.

74. Rogers, H.M.; Glew, L.; Honzák, M.; Hudson, M.D. Prioritizing key biodiversity areas in Madagascar by including data on human pressure and ecosystem services. Landsc. Urban Plan. 2010, 96, 48-56. [CrossRef]

75. Corson, C. A history of conservation politics in Madagascar. Madag. Conserv. Dev. 2017, 12, 49-60. [CrossRef]

76. Sutherland, W.J.; Armstrong-Brown, S.; Armsworth, P.R.; Breeton, T.; Brickland, J.; Campbell, C.D.; Chamberlain, D.E.; Cooke, A.I.; Dulvy, N.K.; Dusic, N.R.; et al. The identification of 100 ecological questions of high policy relevance in the UK. J. Appl. Ecol. 2006, 43, 617-627. [CrossRef]

77. Oldekop, J.A.; Fontana, L.B.; Grugel, J.; Roughton, N.; Adu-Ampong, E.A.; Bird, G.K.; Dorgan, A.; Vera Espinoza, M.A.; Wallin, S.; Hammett, D.; et al. 100 key research questions for the post-2015 development agenda. Dev. Policy Rev. 2016, 34, 55-82. [CrossRef]

78. Pradhan, P.; Costa, L.; Rybski, D.; Lucht, W.; Kropp, J.P. A Systematic Study of Sustainable Development Goal (SDG) Interactions. Earth's Future 2017, 5, 1169-1179. [CrossRef]

79. Wohlin, C. Guidelines for snowballing in systematic literature studies and a replication in software engineering. In Proceedings of the 18th International Conference on Evaluation and Assessment in Software Engineering, London, UK, 13-14 May 2014; pp. 1-10.

80. Gentles, S.J.; Charles, C.; Nicholas, D.B.; Ploeg, J.; McKibbon, K.A. Reviewing the research methods literature: Principles and strategies illustrated by a systematic overview of sampling in qualitative research. Syst. Rev. 2016, 5, 172. [CrossRef]

81. Lecy, J.; Beatty, K. Representative Literature Reviews Using Constrained Snowball Sampling and Citation Network Analysis. Available online: https://ssrn.com/abstract=1992601 (accessed on 16 July 2018).

82. Maxim, L.; Spangenberg, J.H.; O'Connor, M. An analysis of risks for biodiversity under the DPSIR framework. Ecol. Econ. 2009, 69, 12-23. [CrossRef]

83. Dick, M.; Rous, A.M.; Nguyen, V.M.; Cooke, S.J. Necessary but challenging: Multiple disciplinary approaches to solving conservation problems. Facets 2016, 1, 67-82. [CrossRef]

84. McLafferty, S.L. Conducting questionnaire surveys. In Key Methods in Geography; Clifford, N., French, S., Valentine, G., Eds.; Sage Publications Ltd.: Los Angelos, CA, USA, 2010; pp. 77-88.

85. Clifford, N.; French, S.; Valentine, G. (Eds.) Key Methods in Geography, 2nd ed.; Sage Publications Ltd.: Los Angelos, CA, USA, 2010; 545p.

86. Gifford, R.; Nilsson, A. Personal and social factors that influence pro-environmental concern and behaviour: A review. Int. J. Psychol. 2014, 49, 141-157. [CrossRef] [PubMed] 
87. Quinn, G.P.; Keough, M.J. Experimental Design and Data Analysis for Biologists; Cambridge University Press: Cambridge, UK, 2002.

88. Holm, S. A Simple Sequentially Rejective Multiple Test Procedure. Scand. J. Stat. 1979, 6, 65-70.

89. R Core Team. R: A Language and Environment for Statistical Computing. Available online: https://www.Rproject.org/ (accessed on 20 September 2019).

90. Francken, N.; Minten, B. Security and perceptions on justice in rural Madagascar. Dynamics in Social Service Delivery and the Rural Economy of Madagascar: Descriptive Results of the 2004 Commune Survey. Ilo Policy Report. 2005. Chapter 5. Available online: http://www.ilo.cornell.edu/images/chapter5.pdf (accessed on 20 September 2019).

91. Laurance, W.F. The perils of payoff: Corruption as a threat to global biodiversity. Trends Ecol. Evol. 2004, 19, 399-401. [CrossRef] [PubMed]

92. Francken, N.; Minten, B.; Swinnen, J.F. Listen to the Radio! Media and Corruption: Evidence from Madagascar; PRG Working Papers 31872; Katholieke Universiteit Leuven, LICOS - Centre for Institutions and Economic Performance: Leuven, Belgium, 2005.

93. Burnod, P.; Andrianirina Ratsialonana, R.; Teyssier, A. Processus d'acquisition foncière à grande échelle à Madagascar: Quelles régulations sur le terrain ? Cahiers Agric. 2013, 22, 33-38. [CrossRef]

94. Burnod, P.; Gingembre, M.; Andrianirina Ratsialonana, R. Competition over Authority and Access: International Land Deals in Madagascar. Dev. Chang. 2013, 44, 357-379. [CrossRef]

95. Garnett, S.T.; Joseph, L.N.; Watson, J.E.M.; Zander, K.K. Investing in Threatened Species Conservation: Does Corruption Outweigh Purchasing Power? PLoS ONE 2011, 6, e22749. [CrossRef]

96. Gore, M.L.; Ratsimbazafy, J.; Lute, M.L. Rethinking Corruption in Conservation Crime: Insights from Madagascar. Conserv. Lett. 2013, 6, 430-438. [CrossRef]

97. Pimm, S.L.; Ayres, M.; Balmford, A.; Branch, G.; Brandon, K.; Brooks, T.; Bustamante, R.; Costanza, R.; Cowling, R.; Curran, L.M.; et al. Can we defy nature's end? Science 2001, 293, 2207-2208. [CrossRef]

98. Anabel, Y. Andry Rajoelina Unveils Madagascar's New Cabinet. Available online: http://afrika-news.com/ andry-rajoelina-unveils-madagascars-new-cabinet/ (accessed on 13 February 2019).

99. Laurance, W. Madagascar Elections: An Environmental Disaster in Waiting. Available online: https://www. aljazeera.com/indepth/opinion/madagascar-elections-environmental-disaster-waiting-181217095423818. html?fbclid=IwAR2Gj4TD1fa5xCn8yfD93W8XVsfNMOFEW510bqVwtYiAJf_M02LuK2h21g8 (accessed on 17 October 2018).

100. Barrett, M.A.; Brown, J.L.; Morikawa, M.K.; Labat, J.-N.; Yoder, A.D. CITES Designation for Endangered Rosewood in Madagascar. Science 2010, 328, 1109-1110. [CrossRef]

101. Francken, N.; Minten, B.; Swinnen, J.F.M. Media, Monitoring, and Capture of Public Funds: Evidence from Madagascar. World Dev. 2009, 37, 242-255. [CrossRef]

102. Freudenberger, K. Paradise Lost? Lessons Learned from 25 Years of USAID Environment Programs in Madagascar; Final Report U.S. Agency for International Development (USAID); International Resources Group: Washington, DC, USA, 2010.

103. Rakotomanana, H.; Jenkins, R.K.; Ratsimbazafy, J. Conservation challenges for Madagascar in the next decade. In Conservation Biology: Voices from the Tropics; Sodhi, S., Gibson, L., Eds.; John Wiley \& Sons, Ltd: Oxford, UK, 2013; pp. 33-39.

104. UN. Global Indicator Framework for the Sustainable Development Goalsand Targets of the 2030 Agenda for Sustainable Development. Available online: https://unstats.un.org/sdgs/indicators/Global\%20Indicator\% 20Framework\%20after\%20refinement_Eng.pdf (accessed on 15 April 2019).

105. Locatelli, B.; Catterall, C.P.; Imbach, P.; Kumar, C.; Lasco, R.; Marín-Spiotta, E.; Mercer, B.; Powers, J.S.; Schwartz, N.; Uriarte, M. Tropical reforestation and climate change: Beyond carbon. Restor. Ecol. 2015, 23, 337-343. [CrossRef]

106. Shoo, L.P.; Storlie, C.; Vanderlwal, J.; Little, J.; Williams, S.E. Targeted protection and restoration to conserve tropical biodiversity in a warming world. Glob. Chang. Biol. 2011, 17, 186-193. [CrossRef]

107. IUCN. The Bonn Challenge. Available online: http://www.bonnchallenge.org/content/madagascar (accessed on 23 July 2019). 
108. Rabarison, H.; Randrianmahaleo, S.I.; Andriambelo, F.M.; Randrianasolo, H.L.; National Biodiversity Strategy and Action Plans 2015-2025. Decree N ${ }^{\circ}$ 2016-128 of 2016, February 23 Adopting the National Biodiversity Strategy and Action Plans for Madagascar 2015 to 2025. Available online: https://www.cbd.int/doc/world/ mg/mg-nbsap-v2-en.pdf (accessed on 21 November 2018).

109. Chen, I.-C.; Hill, J.K.; Ohlemüller, R.; Roy, D.B.; Thomas, C.D. Rapid range shifts of species associated with high levels of climate warming. Science 2011, 333, 1024-1026. [CrossRef] [PubMed]

110. Bastin, J.-F.; Finegold, Y.; Garcia, C.; Mollicone, D.; Rezende, M.; Routh, D.; Zohner, C.M.; Crowther, T.W. The global tree restoration potential. Science 2019, 365, 76-79. [CrossRef]

111. Sommerville, M.; Milner-Gulland, E.J.; Rahajaharison, M.; Jones, J.P.G. Impact of a Community-Based Payment for Environmental Services Intervention on Forest Use in Menabe, Madagascar. Conserv. Biol. 2010, 24, 1488-1498. [CrossRef]

112. Brimont, L.; Ezzine-de-Blas, D.; Karsenty, A. The cost of making compensation payments to local forest populations in a REDD+ pilot project in Madagascar. Madag. Conserv. Dev. 2017, 12, 25-33. [CrossRef]

113. Rasolofoson, R.A.; Ferraro, P.J.; Ruta, G.; Rasamoelina, M.S.; Randriankolona, P.L.; Larsen, H.O.; Jones, J.P.G. Impacts of Community Forest Management on Human Economic Well-Being across Madagascar. Conserv. Lett. 2017, 10, 346-353. [CrossRef]

114. Neudert, R.; Ganzhorn, J.U.; WÄTzold, F. Global benefits and local costs-The dilemma of tropical forest conservation: A review of the situation in Madagascar. Environ. Conserv. 2016, 44, 82-96. [CrossRef]

115. Danielsen, F.; Skutsch, M.; Burgess, N.D.; Jensen, P.M.; Andrianandrasana, H.; Karky, B.; Lewis, R.; Lovett, J.C.; Massao, J.; Ngaga, Y.; et al. At the heart of REDD+: A role for local people in monitoring forests? Conserv. Lett. 2011, 4, 158-167. [CrossRef]

116. Scales, I.R. Lost in translation: Conflicting views of deforestation, land use and identity in western Madagascar. Geogr. J. 2012, 178, 67-79. [CrossRef] [PubMed]

117. Scales, I.R. The future of conservation and development in Madagascar: Time for a new paradigm? Madag. Conserv. Dev. 2014, 9, 5-12. [CrossRef]

118. Isbell, T. Note to Madagascar's Election Winner: Crime, Infrastructure, and Food Insecurity Most Important Issues for Government to Fix. Afrobarometer Dispatch No. 255. 14 November 2018. Available online: https://afrobarometer.org/sites/default/files/publications/Dispatches/ab_r7_dipatchno255_citizen_ priorities_for_madagascar_government.pdf (accessed on 14 October 2019).

119. Huff, A. Weathering the'long wounded year': Livelihoods, nutrition and changing political ecologies in the Mikea Forest Region, Madagascar. J. Political Ecol. 2014, 21, 83-107. [CrossRef]

120. Fafchamps, M.; Minten, B. Crime, Transitory Poverty, and Isolation: Evidence from Madagascar. Econ. Dev. Cult. Chang. 2006, 54, 579-603. [CrossRef]

121. Raharimalala, O.; Buttler, A.; Schlaepfer, R.; Gobat, J. Quantifying biomass of secondary forest after slash-and-burn cultivation in Central Menabe, Madagascar. J. Trop. For. Sci. 2012, 474-489.

122. Casse, T.; Milhøj, A.; Ranaivoson, S.; Romuald Randriamanarivo, J. Causes of deforestation in southwestern Madagascar: What do we know? For. Policy Econ. 2004, 6, 33-48. [CrossRef]

123. Kull, C.A. Madagascar aflame: Landscape burning as peasant protest, resistance, or a resource management tool? Political Geogr. 2002, 21, 927-953. [CrossRef]

124. Tucker, B.; Huff, A.; Tombo, J.; Hajasoa, P.; Nagnisaha, C. When the wealthy are poor: Poverty explanations and local perspectives in southwestern Madagascar. Am. Anthropol. 2011, 113, 291-305. [CrossRef]

125. Gardner, C.J.; Davies, Z.G. Rural Bushmeat Consumption Within Multiple-use Protected Areas: Qualitative Evidence from Southwest Madagascar. Hum. Ecol. 2014, 42, 21-34. [CrossRef]

126. Dirac Ramohavelo, C.; Sorg, J.-P.; Buttler, A.; Reinhard, M. Recommandations pour une agriculture plus écologique respectant les besoins socio-économiques locaux, région du Menabe Central côte ouest de Madagascar. Madag. Conserv. Dev. 2014, 9, 7. [CrossRef]

127. Filou, E. Illegal corn farming menaces a Madagascar protected area. Mongabay, 21 February 2019.

128. Neudert, R.; Goetter, J.F.; Andriamparany, J.N.; Rakotoarisoa, M. Income diversification, wealth, education and well-being in rural south-western Madagascar: Results from the Mahafaly region. Dev. South. Afr. 2015, 32, 758-784. [CrossRef]

129. Cetas, E.R.; Yasué, M. A systematic review of motivational values and conservation success in and around protected areas. Conserv. Biol. 2017, 31, 203-212. [CrossRef] [PubMed] 
130. Reibelt, L.M.; Woolaver, L.; Moser, G.; Randriamalala, I.H.; Raveloarimalala, L.M.; Ralainasolo, F.B.; Ratsimbazafy, J.; Waeber, P.O. Contact Matters: Local People's Perceptions of Hapalemur alaotrensis and Implications for Conservation. Int. J. Primatol. 2017, 38, 588-608. [CrossRef]

131. Garnett, S.T.; Burgess, N.D.; Fa, J.E.; Fernández-Llamazares, Á.; Molnár, Z.; Robinson, C.J.; Watson, J.E.M.; Zander, K.K.; Austin, B.; Brondizio, E.S.; et al. A spatial overview of the global importance of Indigenous lands for conservation. Nat. Sustain. 2018, 1, 369-374. [CrossRef]

132. Fritz-Vietta, N.V.M.; Tahirindraza, H.S.; Stoll-Kleemann, S. Local people's knowledge with regard to land use activities in southwest Madagascar-Conceptual insights for sustainable land management. J. Environ. Manag. 2017, 199, 126-138. [CrossRef] [PubMed]

133. Thielsen, K. Which form of agreement works for communitybased management? A case study from southwestern Madagascar. Madag. Conserv. Dev. 2016, 11, 66-77. [CrossRef]

134. Pollini, J.; Hockley, N.; Muttenzer, F.D.; Ramamonjisoa, B.S. The transfer of natural resource management rights to local communities. In Conservation and Environmental Management in Madagascar; Routledge: London, UK, 2014; pp. 172-192.

135. Kull, C.A. Empowering Pyromaniacs in Madagascar: Ideology and Legitimacy in Community-Based Natural Resource Management. Dev. Chang. 2002, 33, 57-78. [CrossRef]

136. Nature. Interdisciplinarity: Scientists must work together to save the world. In Special Issue: Interdisciplinarity; Springer Nature Publishing AG.: Berlin, Germany, 2015; Volume 525, p. 7569.

137. Bonebrake, T.C.; Brown, C.J.; Bell, J.D.; Blanchard, J.L.; Chauvenet, A.; Champion, C.; Chen, I.-C.; Clark, T.D.; Colwell, R.K.; Danielsen, F.; et al. Managing consequences of climate-driven species redistribution requires integration of ecology, conservation and social science. Biol. Rev. 2018, 93, 284-305. [CrossRef]

138. Knight, A.T.; Bode, M.; Fuller, R.A.; Grantham, H.S.; Possingham, H.P.; Watson, J.E.M.; Wilson, K.A. Barometer of Life: More Action, Not More Data. Science 2010, 329, 141. [CrossRef]

139. Stuart, S.; Wilson, E.; McNeely, J.; Mittermeier, R.; Rodríguez, J. Response to comments on 'Ecology. The barometer of life'. Science 2010, 329, 141-142. [CrossRef]

140. Cleaver, F. Paradoxes of participation: Questioning participatory approaches to development. J. Int. Dev. 1999, 11, 597-612. [CrossRef]

141. Teye, J. Corruption and illegal logging in Ghana. Int. Dev. Plan. Rev. 2013, 35, 1-19. [CrossRef]

142. Starrfmonline. New Madagascar President Rajoelina Impressed with Ghana's Development. Available online: https://starrfm.com.gh/2019/01/new-madagascar-president-rajoelina-impressed-with-ghanas-devt/ (accessed on 13 April 2019).

143. Tollefson, J. Madagascar's forests face uncertain future. Nature 2019, 565, 407. [CrossRef] [PubMed]

144. Carver, E. Madagascar's next president to take office, bears suspect eco record. Mongabay, 18 January 2019.

145. Ratsimbazafy, J.; Jones, J.; Mittermeier, R. Protect Madagascar's national parks from pillage. Nature 2019, 565, 567. [CrossRef]

146. Jones, J.P.G.; Ratsimbazafy, J.; Ratsifandrihamanana, A.N.; Watson, J.E.M.; Andrianandrasana, H.T.; Cabeza, M.; Cinner, J.E.; Goodman, S.M.; Hawkins, F.; Mittermeier, R.A.; et al. Madagascar: Crime threatens biodiversity. Science 2019, 363, 825. [CrossRef]

147. Wilme, L.; Waeber, P.O. Madagascar: Guard last of the forests. Nature 2019, 565, 567.

(C) 2019 by the authors. Licensee MDPI, Basel, Switzerland. This article is an open access article distributed under the terms and conditions of the Creative Commons Attribution (CC BY) license (http://creativecommons.org/licenses/by/4.0/). 